\title{
SISTEM PENDUKUNG KEPUTUSAN PEMILIHAN PEJABAT KOPERTIS WILAYAH III MENGGUNAKAN METODE ANALYTIC HIERARCHY PROCESS
}

\author{
Adhy Purnama \\ Kopertis Wilayah III \\ Email: adhypurnama1982@gmail.com
}

\begin{abstract}
Abstrak: Sistem Pendukung Keputusan Pemilihan Pejabat Kopertis Wilayah III Menggunakan Metode Analytic Hierarchy Process. Penelitian ini bertujuan untuk mengkaji Metode AHP untuk memberikan solusi dalam pemilihan Pejabat Kopertis Wilayah III yang sebelumnya dilakukan secara konvensional atas faktor subyektif. Teknik pengumpulan data penelitian ini menggunakan metode AHP (Analytical Hierarchy Process), wawancara, dan kuisioner. Hasil penelitian menunjukkan bahwa berdasarkan kriteria kemampuan manajerial, kualitas kerja, pengetahuan dan skill, tanggung jawab, komunikasi dan kerjasama, motivasi, dan disiplin kerja diperoleh prioritas tertinggi sebagai calon pejabat Kopertis Wilayah III dengan skor 0.409.
\end{abstract}

Kata kunci: Analytical Hierarchy Process, kriteria seleksi, prioritas, prioritas global, sistem pemilihan

\begin{abstract}
The Election Support System of Official Kopertis Region III Using the Analytic Hierarchy Process Method. This study was aimed at finding out how AHP can provide solutions to problems of election officials Kopertis Region III previously done conventionally on subjective factors. In this research, the data were collected though AHP (Analytical Hierarchy Process), interviews, and questionnaires. The results shows that based on the criteria: managerial ability, quality of work, knowledge and skills, responsibility, communication and cooperation, motivation, and work discipline obtained, the highest priority as the official candidate of Kopertis Region III is Mr. Topan ST, MM (pseudonym) with the score of 0.409 .
\end{abstract}

Keywords: a global priority, Analytical Hierarchy Process, the electoral system, priorities, the selection criteria

\section{PENDAHULUAN}

Fungsi Kopertis sebagai kordinasi perguruan tinggi swasta, kini menjadi lembaga layanan perguruan tinggi berdasarkan UU No 12 Tahun 2012. Hal ini mengisyaratkan bahwa terdapat tanggung jawab yang besar dalam peningkatan mutu pendidikan tinggi di wilayah Kopertis III. Menurut data dari Pangkalan Data pendidikan Tinggi (PPDIKTI), jenis perguruan tinggi yang berada di bawah koordinasi Kopertis
Wilayah III di antaranya: Akademi (118), Politeknik (7), Sekolah Tinggi (115), Institut (15), dan Universitas (51). Dengan menjadi lembaga layanan perguruan tinggi di antaranya Perguruan Tinggi Negeri (PTN) yaitu Universitas Indonesia (UI), Institut Pertanian Bogor (IPB), dan Universitas Negeri Jakarta (UNJ), maka ketiga PTN tersebut menjadi bagian dari tanggung jawab Kopertis. Untuk itu tenaga kependidikan yang ada dalam kelembagaan Kopertis saat 
ini harus mempunyai kehandalan dalam sumberdaya manusianya.

Salah satu aspek penting yang menentukan keberhasilan sebuah satuan kerja pendidikan adalah terselenggaranya aktivitas organisasi secara efisien. Untuk kepentingan itu diperlukan manajemen yang profesional didukung penyelenggaraan administrasi yang profesional pula, yang ditangani oleh pejabat tenaga kependidikan yang kompeten dalam bidangnya (Muhyadi, 2013: 39). Semakin tinggi keterampilan manajerial, maka akan semakin tinggi keefektifan organisasi (Salabi, 2014: 125).

Kopertis Wilayah III didukung tiga bagian utama organisasi yaitu: 1) kelembagaan dan sistem informasi, 2) bagian umum, dan 3) bidang akademik kemahasiswaan dan ketenagaan. Bagian kelembagaan yang membawahi subbagian kelembagaan dan kerjasama, serta subbagian sistem informasi. Bagian umum membawahi subbagian kepegawaian, sub tata usaha, sub keuangan. Bagian akademik kemahasiswaan \& ketenagaan, membawahi sub bagian akademik \& kemahasiswaan.

Bagian ketenagaan saat ini sangat membutuhkan hadirnya Kepala Sub Bagian (Kasubag) Sistem Informasi. Dalam proses kegiatan organisasi tentu ada penggantian kedudukan pimpinan yang disebabkan oleh beberapa faktor di antaranya mutasi, pensiun, meninggal, atau lelang jabatan. Oleh karena itu, pilihan dalam menempatkan seseorang layak atau tidak harus memenuhi kriteria yang diharapkan mampu membawa perubahan signifikan organisasi menjadi lebih baik.

Upaya penentuan secara objektif kenaikan jabatan akan sangat bermanfaat untuk memotivasi karyawan supaya dapat bekerja dengan baik. Ketepatan penempatan seseorang pada sebuah jabatan akan membawa dampak strategis bagi kelangsungan organisasi. Istilah "the right man on the right job" secara jelas menggambarkan bahwa posisi strategis dalam suatu lembaga struktural seharusnya ditempati oleh orangyang tepat sesuai dengan keahlian dan pengetahuan yang dimilikinya (Nasibu, 2009: 180).

Upaya untuk penentuan kenaikan jabatan karyawan ini terdiri dari sejumlah kriteria yang perlu dipertimbangkan dengan adanya sejumlah alternatif karyawan. Untuk pertama kali metode AHP diperkenalkan oleh Thomas L. Saaty pada periode tahun 1971-1975 di Wharton School (Kosasi, 2002: 6). Metode AHP ini pada awalnya digunakan untuk menentukan sekolah yang terbaik bagi anaknya.

Penelitian ini bertujuan adalah mengkaji metode AHP dapat memberikan solusi dalam permasalahan pemilihan Pejabat Kopertis Wilayah III dan model sistem pendukung keputusan pemilihan Pejabat Kopertis Wilayah III yang berbasis komputer dengan menggunakan metode AHP. Manfaat dari tulisan ini adalah menerapkan metode Analytical Hierarchy Process (AHP) dalam membangun sistem pendukung keputusan pemilih-an pejabat Kopertis Wilayah III khususnya pejabat kepala subbagian sistem informasi dengan prioritas dari sumberdaya manusia terbaik Kopertis Wilayah III .

\section{METODE}

Penelitian ini dilakukan di Kopertis Wilayah III. Penelitian ini adalah menggunakan metode kualitatif dengan pendekatan studi kasus. Metode kualitatif yang digunakan adalah metode purposive random sampling. Data dikumpulkan melalui kuisioner. Responden berasal dari koordinator Kopertis Wilayah III. 
Dalam penelitian ini, metode AHP diaplikasikan pada sistem pengembangan SDM, khususnya untuk menentukan calon pejabat struktural seperti Kepala Sub Bagian/Kepala Bagian pada Kopertis Wilayah III. Untuk penentuan bakal calon, diasumsikan bahwa kriteria-kriteria yang digunakan dalam menilai bakal calon adalah kemampuan manajerial, kualitas kerja, pengetahuan dan skill, tanggung jawab, komunikasi dan kerjasama, motivasi, dan disiplin kerja, serta mempunyai tingkat pendidikan dan golongan yang memenuhi syarat calon pejabat struktural.

Sebagai suatu penelitian, nama-nama bakal calon yang diberikan disamarkan. Untuk menentukan prioritas antarkriteria, disesuaikan dengan kebutuhan sebagai pejabat struktural oleh Koordinator Kopertis Wilayah III. Dengan demikian dalam pengisian nilai prioritas koordinator Kopertis Wilayah III mempunyai kewenangan yang penuh dengan masukan dari sekretaris pelaksana.

Kewenangan penuh ini termasuk pengisian nilai prioritas antarcalon pejabat struktural untuk masing-masing kriteria. Untuk hal-hal yang bersifat kuantitatif misalkan kriteria disiplin kerja, Kordinator Kopertis Wilayah III dapat menggunakan data yang tersedia, yaitu absensi kehadiran. Untuk kriteriakriteria yang lain, Kordinator Kopertis Wilayah III dapat menggunakan data- data yang bersifat kualitatif, hasil dari pengamatan langsung maupun informasi dari rekan sejawat dan dari bawahan jika calon pejabat struktural pernah menjadi pejabat struktural pada tempat tertentu.

Hasil perhitungan dengan geometric mean tiap responden, akhirnya akan digabungkan, dan nilai hasil penggabungan tersebut akan dihitung tingkat consistency ratio-nya (CR) menggunakan tool Expert Choice 2000. Data statistik tersebut didapatkan dari kuisioner dengan menggunakan metode pendekatan AHP. Kemudian diuji dengan menggunakan tool atau software Expert Choice 2000.

Dengan langkah menentukan jenis jabatan struktural, kriteria-kriteria yang diperlukan, dan nama calon pejabat struktural. Kuisioner disusun dalam bentuk pertanyaan dengan mengacu kepada hirarki yang telah dibuat dari kriteria-kriteria dan sub-sub kriteria berdasarkan skala 1-9 atau nilai perbandingan (Tabel 1) dengan metode Pairwise Comparison.

\section{HASIL DAN PEMBAHASAN}

Model pendukung keputusan AHP ini akan menguraikan masalah multi faktor atau multi kriteria yang kompleks menjadi suatu hirarki. Menurut Saaty (1990: 9-26), AHP sering digunakan sebagai metode pemecahan masalah dibanding dengan metode yang lain karena: a) struktur yang berhirarki, sebagai konsekuesi dari kri-

Tabel 1. Nilai Perbandingan

\begin{tabular}{ll}
\hline Nilai 1 & Kedua faktor sama pentingnya \\
Nilai 3 & Faktor yang satu sedikit lebih penting daripada faktor yang lainnya \\
Nilai 5 & Faktor satu esensial atau lebih penting daripada faktor lainnya \\
Nilai 7 & Satu faktor jelas lebih penting daripada faktor lainya \\
Nilai 9 & Satu faktor mutlak lebih penting daripada faktor lainnya \\
Nilai 2, 4,6,8 & Nilai-nilai antara, diantara dua nilai pertimbangan yang berdekatan \\
\hline
\end{tabular}


teria yang dipilih, sampai pada subkriteria yang paling dalam. b) Memperhitungkan validitas sampai dengan batas toleransi inkonsistensi berbagai kriteria dan alternatif yang dipilih oleh pengambil keputusan. c) Memperhitungkan daya tahan output analisis sensitivitas pengambilan keputusan. Struktur hirarkhi AHP disajikan pada Gambar 1

Menurut Daihani (2001: 54), konsep Sistem Pendukung Keputusan (SPK) pertama kali diungkapkan pada awal tahun 1970-an oleh Michael S. Scott Morton yang menjelaskan bahwa SPK adalah suatu sistem yang berbasis komputer yang ditujukan untuk membantu pengambil keputusan dalam memanfaatkan data dan model tertentu untuk memecahkan berbagai persoalan yang tidak terstruktur. Seiring dengan perkembangan teknologi informasi dan perkembangan tuntutan Perguruan Tinggi baik Negeri maupun Swasta sebagai World Class University yang handal, guna menghadapi datangnya Masyarakat Ekonomi ASEAN (MEA) menyebabkan persyaratan untuk terpilih menjadi Pejabat Kopertis Wilayah III menjadi kompleks.

Perkembangan informasi dan komunikasi, pesatnya perkembangan ilmu pengetahuan dan teknologi serta perubahan struktur ketenagakerjaan di era global memerlukan kualitas Sumber Daya Manusia (SDM) yang handal (Wagiran, Munadi, \& Widodo, 2014: 92). Berdasarkan ketujuh kriteria yang dimasukkan ke dalam Software AHP berupa Expert choice, didapat kerangka pemilihan alternatif, terlihat di Gambar 2 .

Terdapat tujuh kriteria dalam pemilihan pejabat Kopertis Wilayah III, yaitu kemampuan manajerial, kualitas kerja, pengetahuan dan skill, komunikasi dan kerja sama, motivasi serta semangat, dengan tiga kandidat terbaik yang dimiliki oleh Kopertis Wilayah III.Keberadaan hierarki memungkinkan dipecahnya masalah kompleks atau tidak terstruktur ke dalam sub-sub masalah, lalu menyusunnya menjadi suatu bentuk hierarki (Kusrini, 2007: 137).

Dilanjutkan dengan menentukan Tingkat Sensivitas Hasil Analisis Inconsistency ratio atau rasio inkonsistensi. Data responden merupakan parameter yang digunakan untuk memeriksa apakah perbandingan berpasangan telah dilakukan dengan konsekuen atau tidak.

Rasio inkonsistensi data dianggap baik jika nilai $C R-n y a \leq 0.1$. Jika rasio inkonsistensi lebih besar dari 10\% maka akan dilakukan pengambilan data ulang, dan bila rasio inkonsistensi lebih

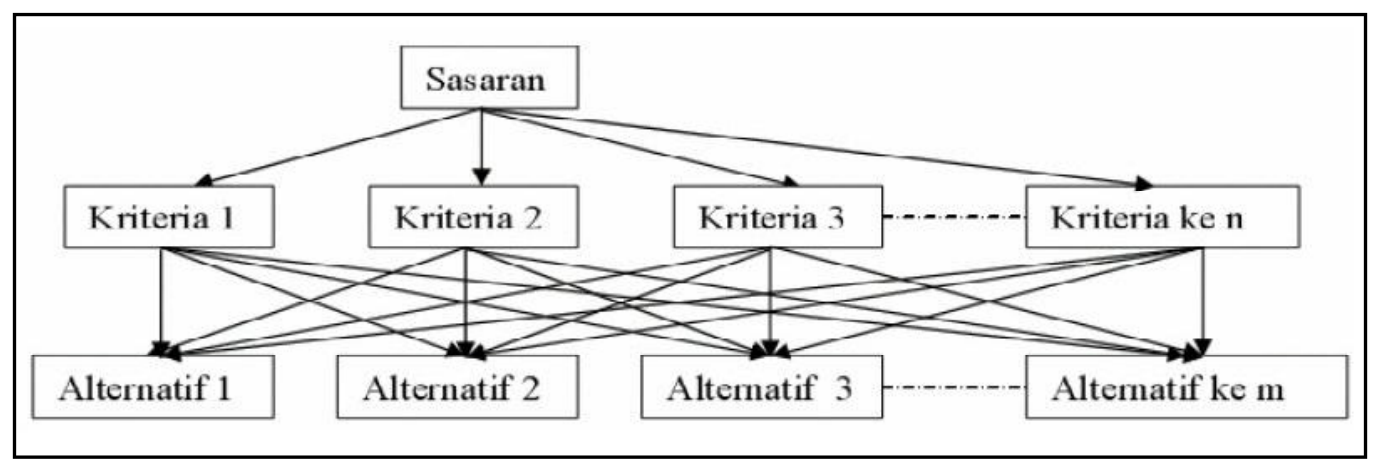

Gambar 1. Struktur Hierarki AHP 


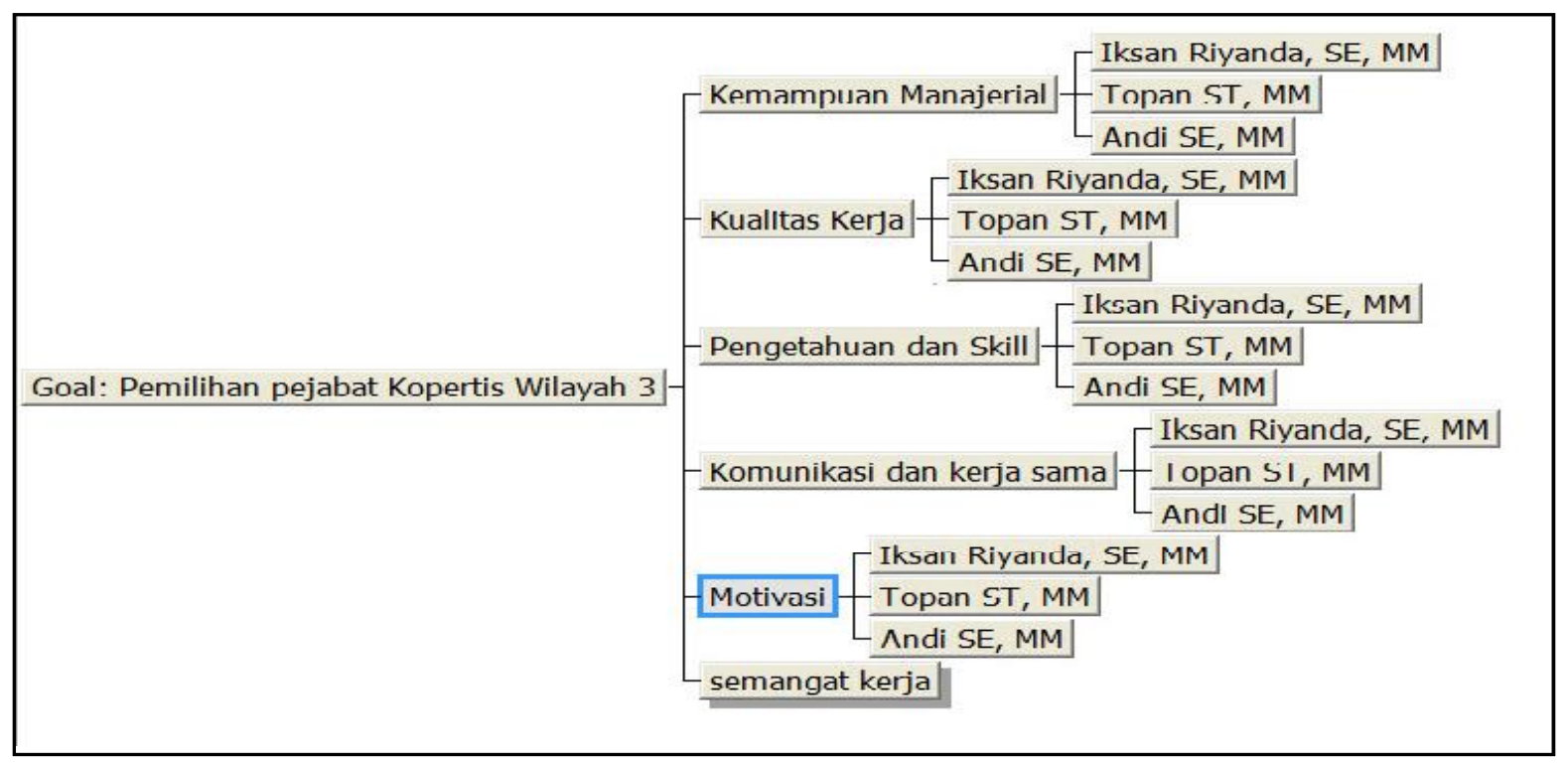

Gambar 2. Kerangka Rancangan Pemilihan Alternatif

kecil dari 10\% maka akan dilanjutkan dengan pembobotan tiap elemen. Untuk mengecek rasio inkonsistensi data responden, berikut ini ditampilkan nilai rasio inkonsistensi pada masing-masing matriks perbandingan.

Berdasarkan Tabel 2, dapat disimpulkan bahwa perbandingan berpasangan yang diberikan responden ahli memiliki nilai rasio inkonsistensi yang lebih kecil dari 0,1 sebagai batas maksimum nilai rasio inkonsistensi. Dengan demikian hasil perhitungan geometrik gabungan data responden cukup konsisten. Bobot masing-masing kriteria sistem pendukung keputusan untuk menentukan prioritas pejabat Kopertis Wilayah III disajikan dalam Gambar 3 sampai Gambar 10.

Tabel 2. Perbandingan Elemen dan Nilai CR

\begin{tabular}{ccc}
\hline No & \multicolumn{1}{c}{ Matrix Perbandingan Elemen } & Nilai CR \\
\hline 1 & $\begin{array}{c}\text { Perbandingan Elemen Level 1 berdasarkan sasaran pemilihan Pejabat } \\
\text { Kopertis Wilayah III }\end{array}$ & 0,08 \\
2 & $\begin{array}{c}\text { Perbandingan elemen sub kriteria level II kriteria Kemampuan Mana- } \\
\text { jerial }\end{array}$ & 0,00 \\
3 & Perbandingan elemen sub kriteria level II kriteria Kualitas Kerja & 0,05 \\
4 & Perbandingan elemen sub kriteria level II kriteria Pengetahuan \& Skil & 0,00 \\
5 & Perbandingan elemen sub kriteria level II kriteria Komunikasi \& kerja & 0,00 \\
& sama & 0,00 \\
6 & Perbandingan elemen sub kriteria level II kriteria motivasi & 0,00 \\
7 & Perbandingan elemen sub kriteria level II Kriteria Semangat Kerja & \\
\hline
\end{tabular}


Dari berbagai sumber daya yang dimiliki perusahaan, SDM menempati posisi strategis di antara sumber daya lainnya. Tanpa SDM, sumber daya yang lain tidak bisa dimanfaatkan apalagi dikelola untuk menghasilkan suatu produk. Tetapi dalam kenyataanya masih banyak perusahaan tidak menyadari pentingnya SDM bagi kelangsungan hidup perusahaan. Masih banyak perusahaan yang menganggap SDM adalah aset organisasi yang paling penting, karena SDM yang menggerakkan dan membuat sumber daya lainnya bekerja (Ellitan, 2002: 66).

Berdasarkan Gambar 3, hasil pengolahan data responden ahli berdasarkan software Expert Choice 2000, menunjukkan bahwa prioritas utama atau tertinggi yaitu kriteria kemampuan pengetahuan \& skill dengan nilai bobot 0,224 atau sebanding dengan $22,4 \%$ dari total kriteria. Peringkat prioritas kriteria yang terakhir adalah kualitas kerja dengan nilai bobot 0,098 atau sebanding dengan 9,8\% dari total kriteria.

Pengolahan data responden ahli software Expert Choice 2000 yang disajikan pada Gambar 4, menunjukkan bahwa prioritas utama atau tertinggi yaitu Ikhsan Riyanda S.T., M.M. dengan nilai bobot 0,778 atau sebanding dengan 77,8\% dari total kriteria. Peringkat prioritas kriteria sama adalah dimiliki oleh kedua kandidat yaitu Topan S.T., M.M. dan Andi, S.E., M.M. dengan nilai bobot 0,111 masing-masing atau sebanding dengan $11,1 \%$ dari total kriteria.

Gambar 5 menunjukkan hasil pengolahan data responden ahli software Expert Choice 2000 yang terkait dengan kualitas kerja, yang menunjukkan bahwa prioritas utama atau tertinggi yaitu Topan S.T., M.M. dengan nilai bobot 0,574 atau sebanding dengan $57,41 \%$ dari total kriteria. Peringkat prioritas kriteria yang terakhir adalah Ikhsan Riyanda, S.E., M.M. dengan nilai bobot 0,065 atau sebanding

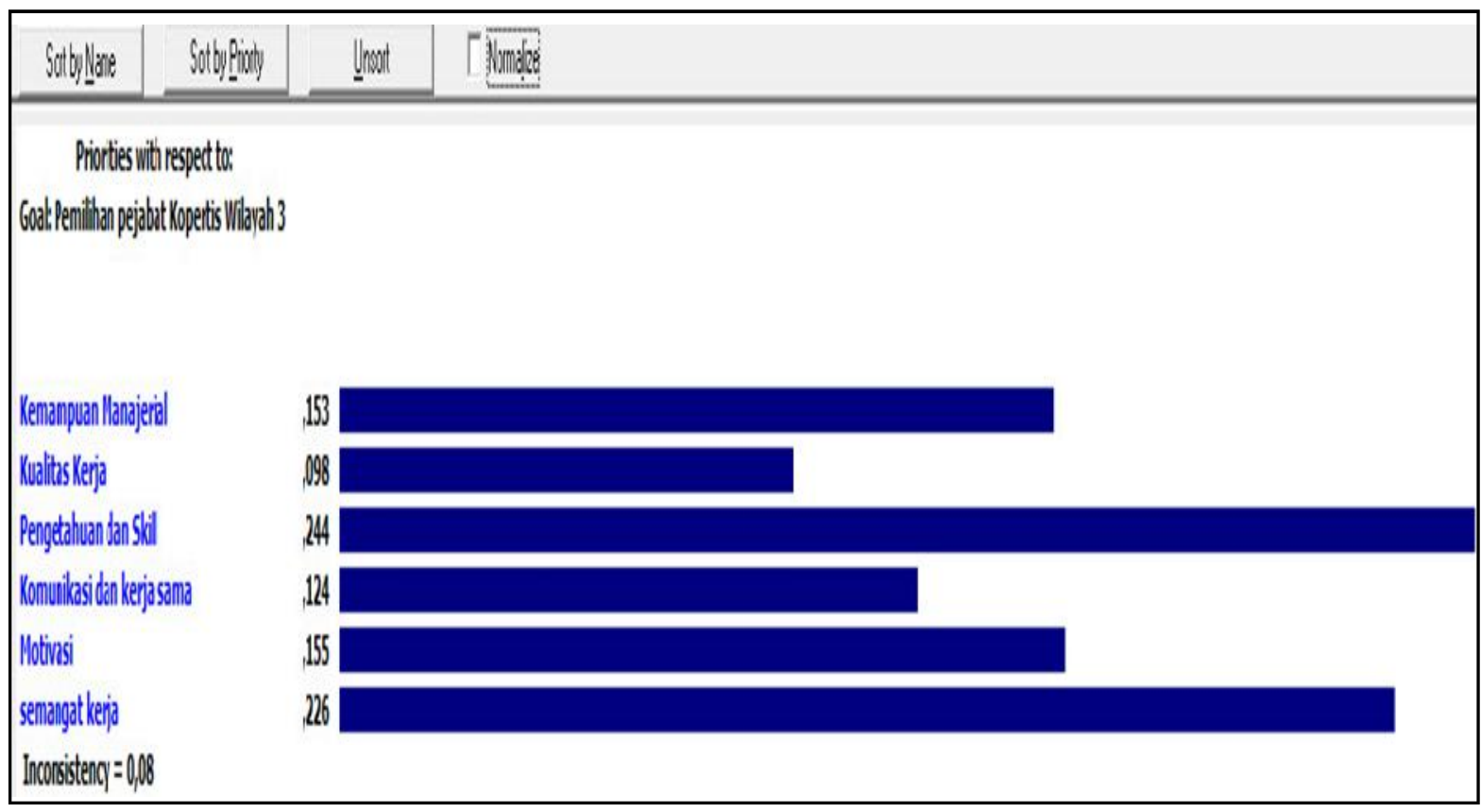

Gambar 3. Kriteria Pemilihan Pejabat Kopertis Wilayah III 


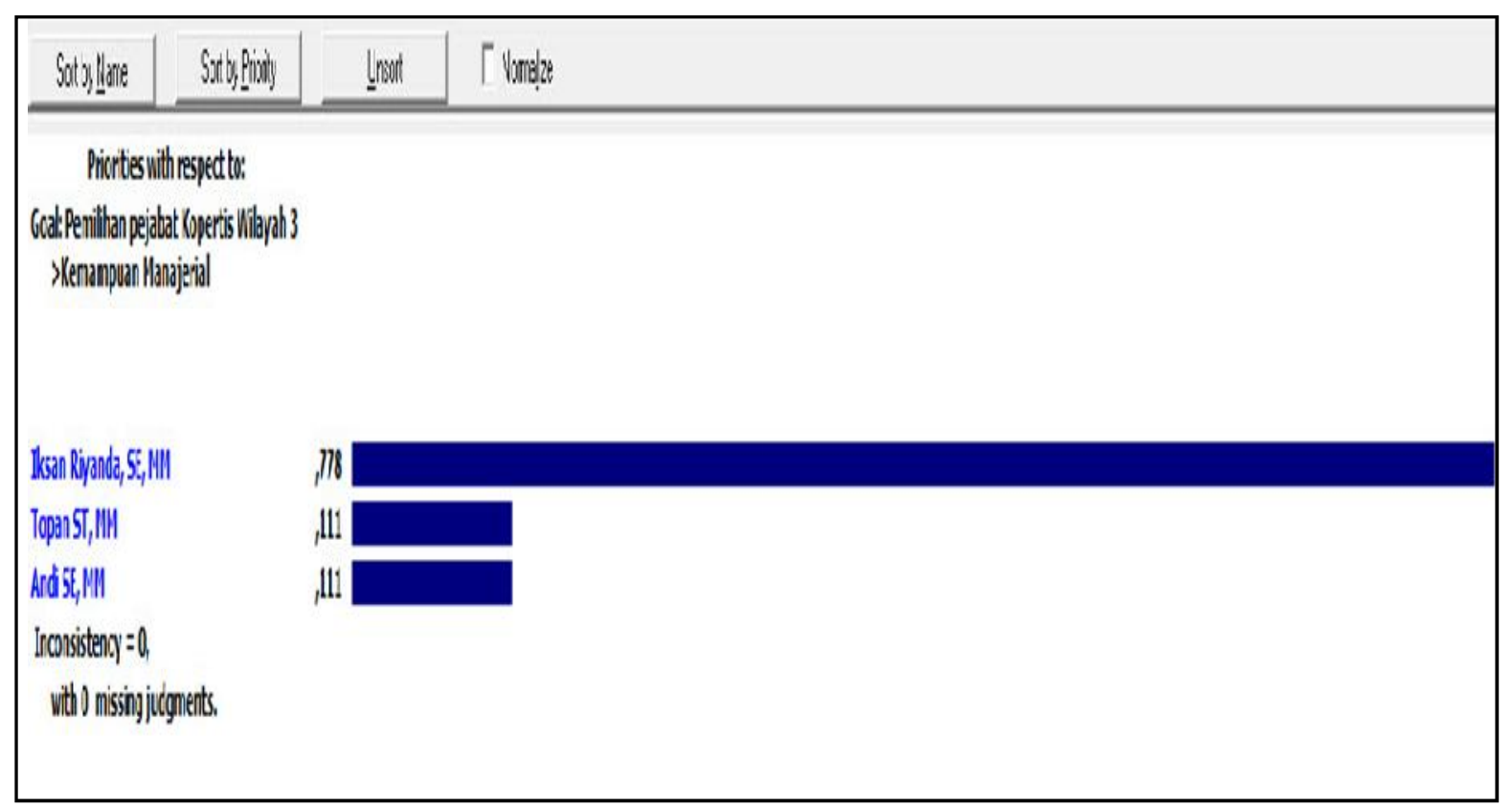

Gambar 4. Kriteria Kemampuan Manajerial Beserta Nilai Bobot Prioritas

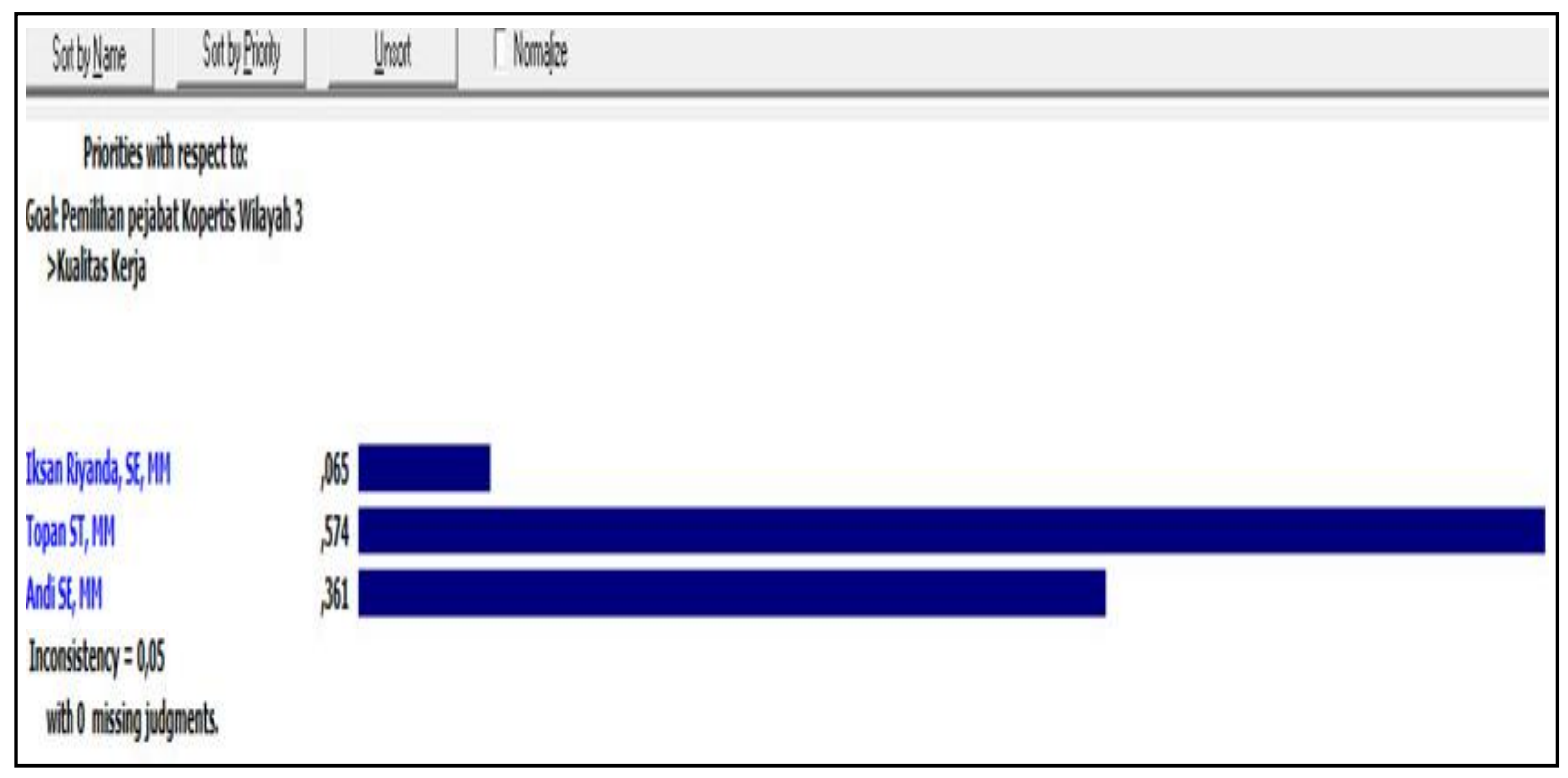

Gambar 5. Kriteria Kualitas Kerja Beserta Nilai Bobot

dengan 6,5\% dari total kriteria. Sistem yang telah di kembangkan dengan metode AHP ini, dapat digunakan dengan jumlah faktor kriteria yang ditentukan oleh user sendiri, sehingga dapat disesuaikan dengan kebutuhan (Tominanto, 2012: 14).
Berdasarkan Gambar 6, hasil pengolahan data responden ahli software Expert Choice 2000 yang terkait dengan pengetahuan dan skill, menunjukkan bahwa prioritas utama atau tertinggi yaitu Topan S.T., M.M. dan Andi SE dengan nilai bobot 0,476 atau sebanding dengan 


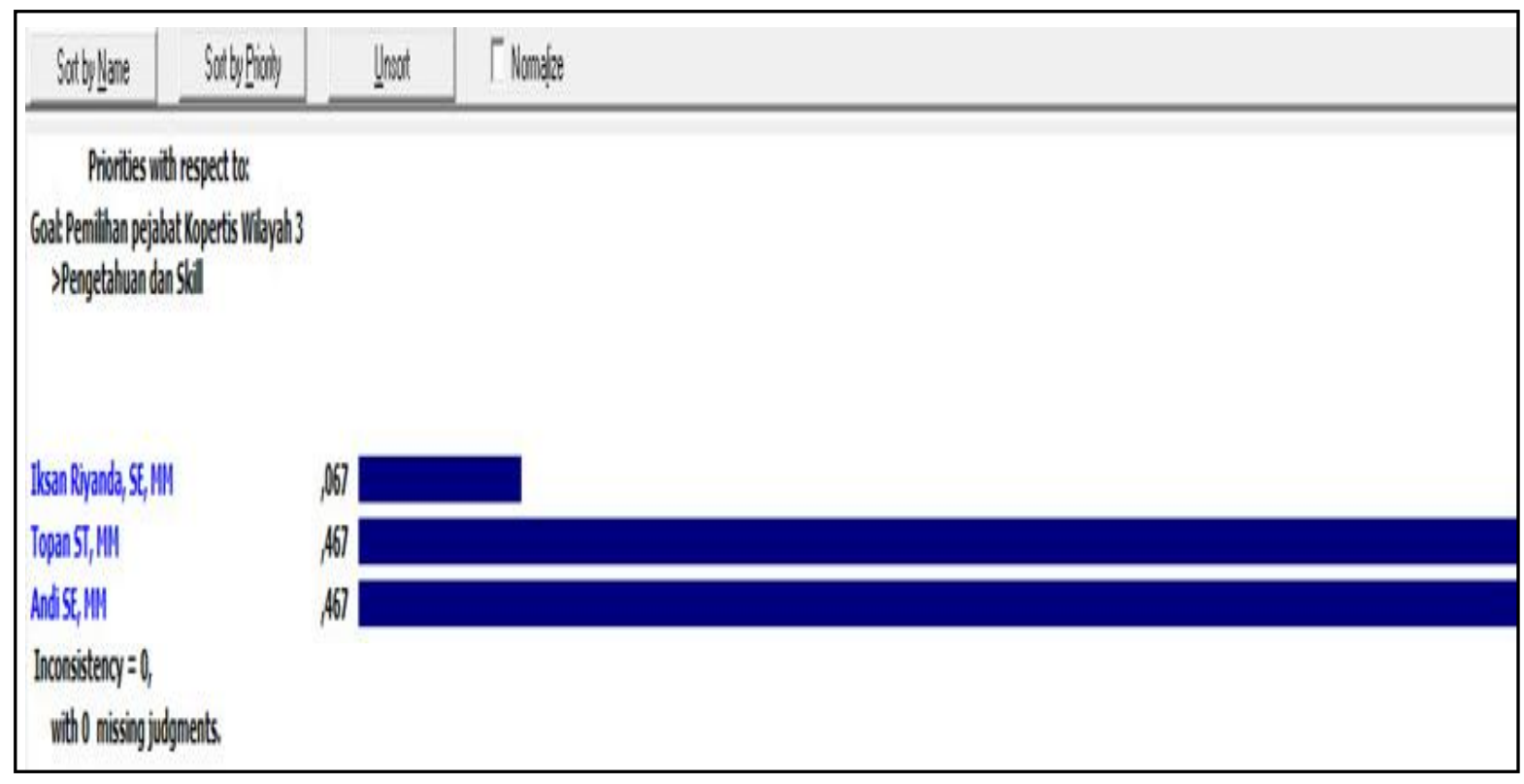

Gambar 6. Kriteria Pengetahuan \& Skill Beserta Nilai Bobot Prioritas

47,6\% dari total kriteria. Peringkat prioritas kriteria yang terakhir adalah Ikhsan Riyanda, S.E., M.M. dengan nilai bobot 0,067 atau sebanding dengan $6,7 \%$ dari total kriteria pengetahuan dan skill. Hasil pengolahan data responden ahli software Expert Choice 2000 yang disajikan pada Gambar 7, menunjukkan bahwa prioritas utama atau tertinggi yaitu Ikhsan Riyanda, S.E., M.M. dengan nilai bobot 0,778 atau sebanding dengan $77,8 \%$ dari total kriteria. Peringkat prioritas kriteria yang terakhir adalah Topan, S.T., M.M. dan Andi, S.E dengan nilai bobot 0,111 masing-masing atau sebanding dengan $11,1 \%$ dari total kriteria komunikasi.

\begin{tabular}{|c|c|c|c|}
\hline Satbly live & 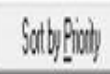 & Unowot & T Nondere \\
\hline \multicolumn{4}{|c|}{ 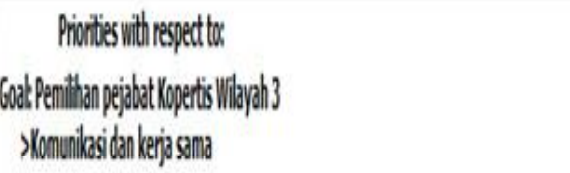 } \\
\hline \multicolumn{4}{|c|}{ 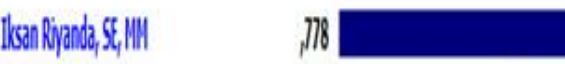 } \\
\hline \multirow{2}{*}{\multicolumn{4}{|c|}{ Topans, I, HI }} \\
\hline & & & Anobis, \\
\hline \multicolumn{4}{|c|}{ Inconsisteny=0, } \\
\hline \multicolumn{4}{|c|}{ vitho misiminjughnetss } \\
\hline
\end{tabular}

Gambar 7. Kriteria Komunikasi dan Kerja Sama Beserta Nilai Bobot Prioritas 
Gambar 8 menunjukkan hasil pengolahan data responden ahli software Expert Choice 2000 berdasarkan kriteria motivasi. Diperoleh hasil bahwa prioritas utama atau tertinggi yaitu Topan, S.T., M.M. dan Andi, S.E., M.M. dengan nilai bobot 0,467 masing-masing atau sebanding dengan $46,7 \%$ dari total kriteria. Peringkat prioritas kriteria yang terakhir adalah Ikhsan Riyanda S.T., M.M. dengan nilai bobot 0,067 atau sebanding dengan 6,7\% dari total kriteria motivasi.

Berdasarkan hasil pengolahan data responden ahli software Expert Choice 2000 yang disajikan pada Gambar 9, diperoleh hasil bahwa prioritas utama

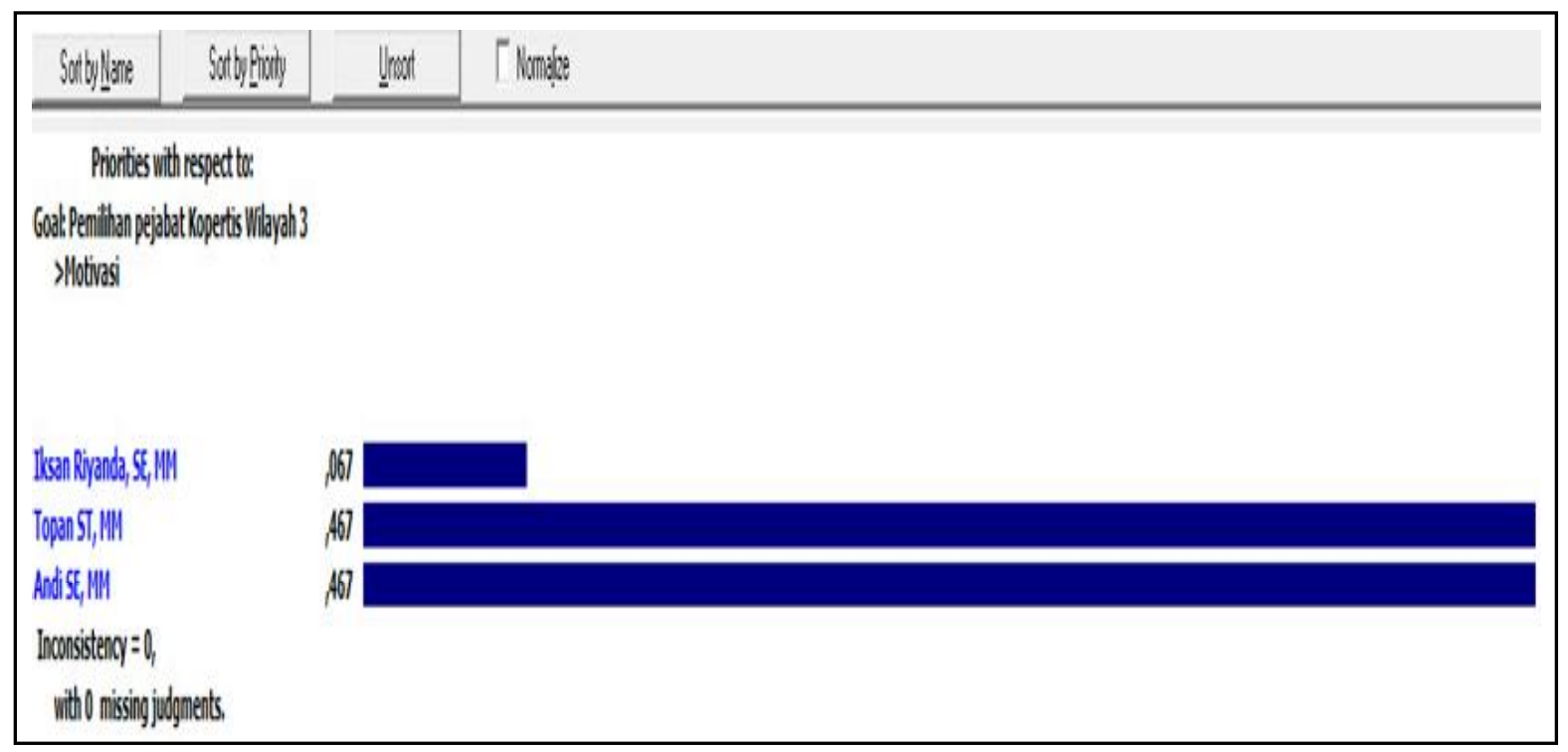

Gambar 8. Kriteria Motivasi Beserta Nilai Bobot Prioritas

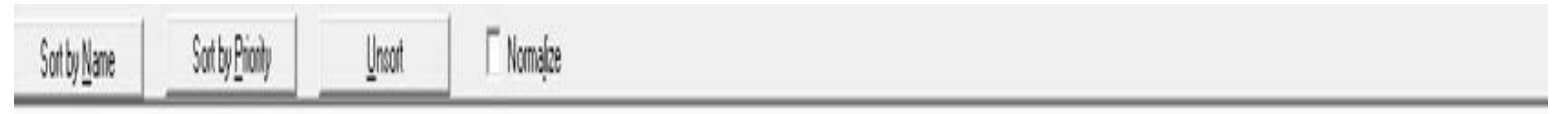

Prionitios with sespedto:

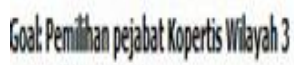

semanad kerpa

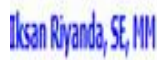 \\ Iopans, 5, , WI \\ Andist, \\ Inconsistency: $=0$, \\ vitho missingujugnenths}

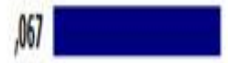

(A6)

1467

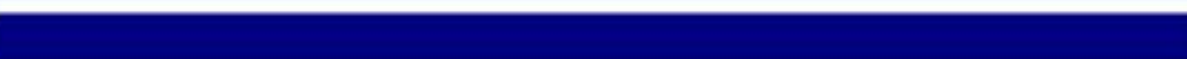

Gambar 9. Kriteria Semangat Kerja Beserta Nilai Bobot 
atau tertinggi yaitu Topan, S.T., M.M. dan Andi, S.E., M.M. dengan nilai bobot 0,467 masing-masing atau sebanding dengan $46,7 \%$ dari total kriteria. Peringkat prioritas kriteria yang terakhir adalah Ikhsan Riyanda, S.E., M.M. dengan nilai bobot 0,067 atau sebanding dengan 6,7\% dari total kriteria semangat kerja.

Gambar 10 menyajikan hasil pengolahan data responden ahli software Expert Choice 2000. Diperoleh hasil bahwa prioritas utama atau tertinggi adalah Topan, S.T., M.M. dengan nilai bobot 0,479 atau sebanding dengan $47,9 \%$ dari total alternatif yang ditetapkan.

Peringkat prioritas alternatif berikutnya adalah Andi, S.E., M.M. dengan nilai bobot 0,339 atau sebanding dengan 33,9\% dari total alternatif yang ditetapkan. Peringkat prioritas alternatif yang terakhir adalah Ikhsan Riyanda, S.E., M.M. dengan nilai bobot 0,202 atau sebanding dengan 20,2\% dari total alternatif yang ditetapkan.

Bentuk struktur keputusan pada software Expert Choice mengenai proses pemilihan pejabat kopertis wilayah III Dapat dilihat dalam Gambar 11. Jika dilihat dalam bentuk grafik performa keseluruhan kandidat berdasarkan ketujuh kriteria yang digunakan, maka dapat dilihat pada tampilan Gambar 12.

Hasil sistem pendukung keputusan ini diharapkan pejabat terkait (misal Koordinator Kopertis Wilayah III) tidak akan kesulitan dalam memilih siapa pegawai yang paling berprestasi (Kusrini, 2007: 15).

Pada Gambar 12 diagram Sensitivity Analysis dapat dilihat bahwa dengan berdasarkan kriteria-kriteria yang telah ditentukan, dan telah melalui proses assessment masing-masing maka diperoleh hasil pemilihan kelayakan pemilihan calon Pejabat Kopertis Wilayah III kepala sub bagian Sistem Informasi adalah Topan, S.T., M.M., Perlu diingat bahwa besarnya investasi yang dilakukan di sektor SDM tidak akan membawa hasil yang baik disertai peningkatan kualitas SDM yang dibutuhkan dan sarana-sarana penunjang (Koni, 2009: 179).

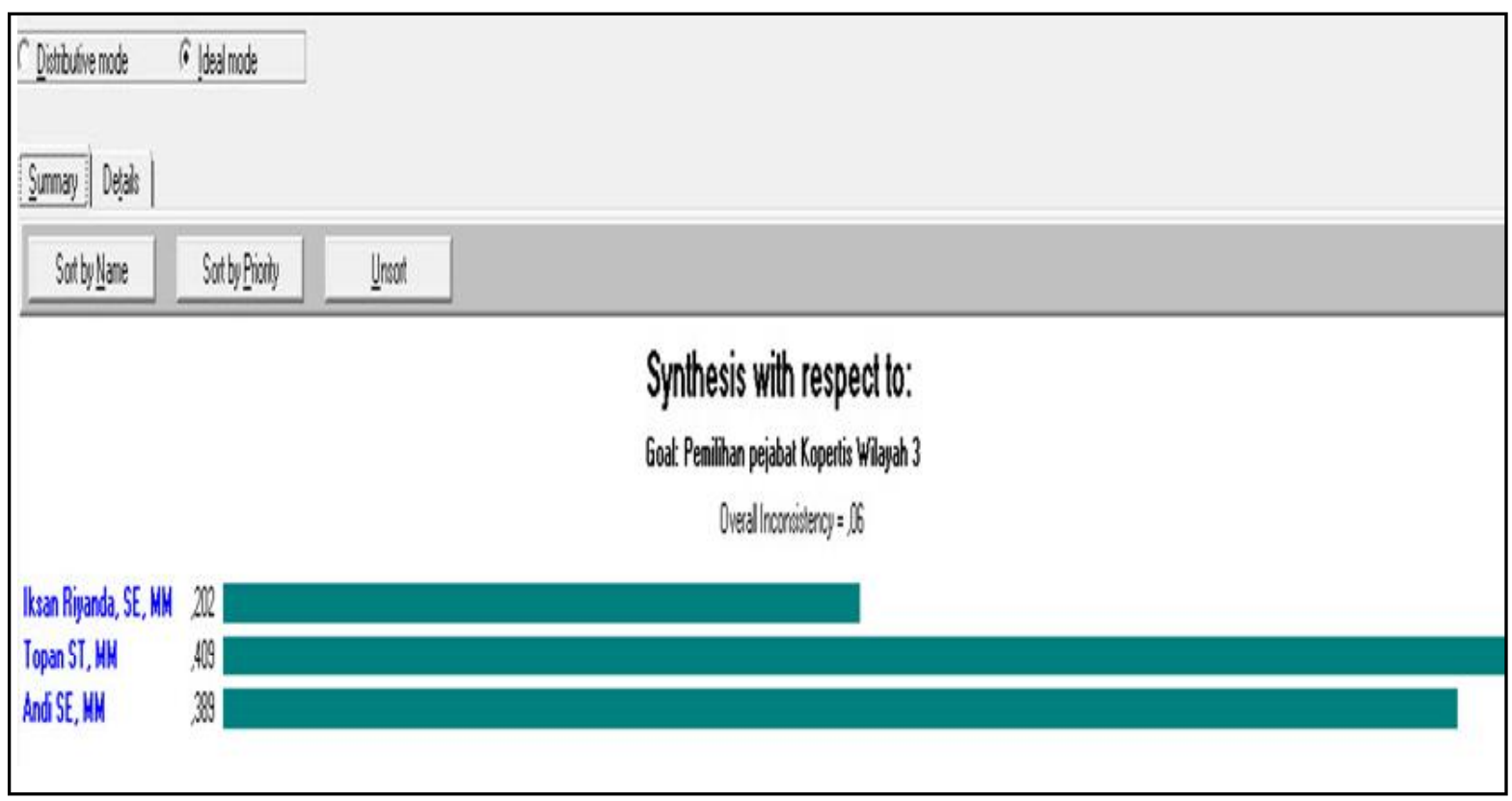

Gambar 10. Hasil Synthesis with respect 


\begin{tabular}{|c|c|}
\hline 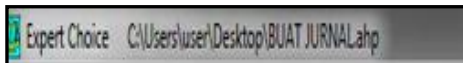 & $00 \frac{1}{x}$ \\
\hline \multicolumn{2}{|l|}{ 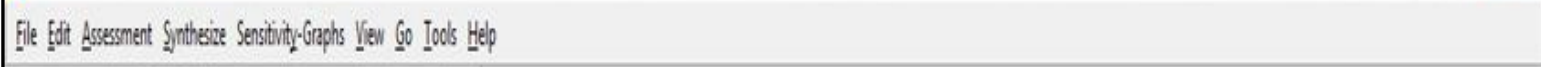 } \\
\hline \multicolumn{2}{|l|}{ 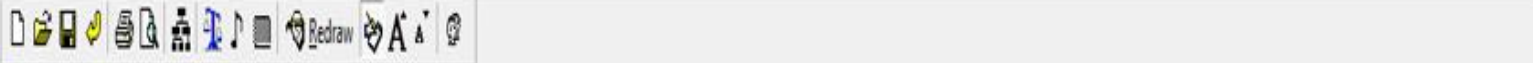 } \\
\hline \multicolumn{2}{|l|}{ 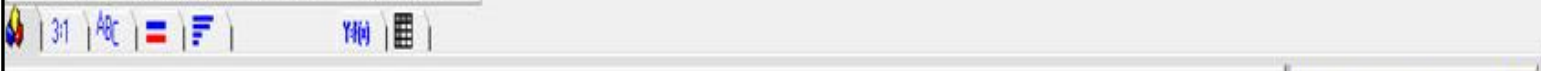 } \\
\hline & 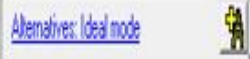 \\
\hline Goal: Penillian pejabat Kopertis Wilayah33 & Iksan Rivanda S 202 \\
\hline J Kemampuan Manajerial $(L \mathbf{L}, 153)$ & IIJdil hildadud, \\
\hline \multirow{2}{*}{ - Kualitas Kerja (L:,098) } & lopan SI, MM .409 \\
\hline & Dengetahuan dan Skill (L; ,244) \\
\hline \multicolumn{2}{|l|}{ ¿Komunikasi dan kerja sama (Li, 124) } \\
\hline \multicolumn{2}{|l|}{ Motivasi (L: 155) } \\
\hline \multicolumn{2}{|l|}{ - \semangat kerja (L; 226) } \\
\hline & 111 \\
\hline & Intemsion Dowanean \\
\hline
\end{tabular}

Gambar 11. Penstrukturan Keputusan dan Pengambilan Keputusan

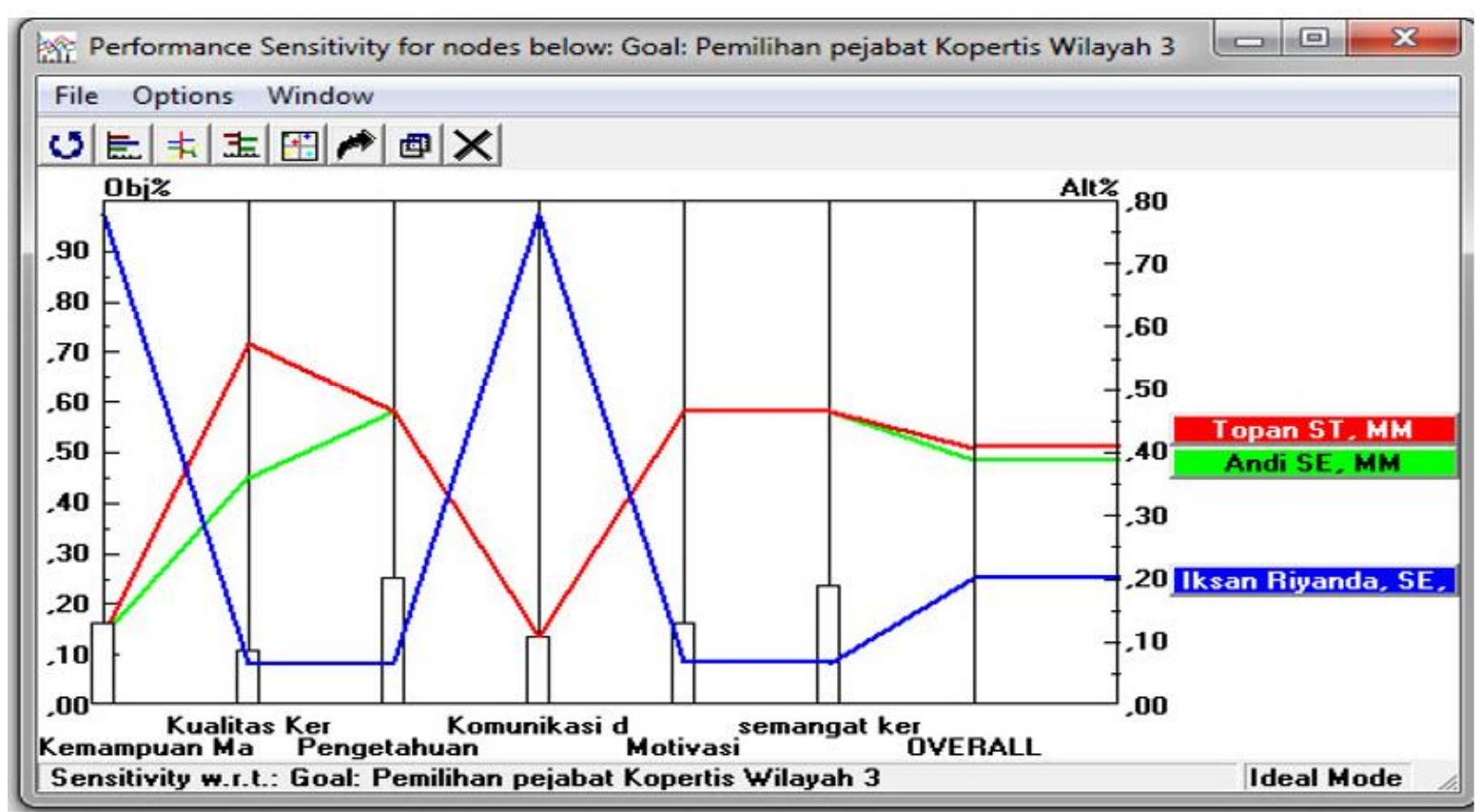

Gambar 12. Diagram Performa Sensivity Analysis

\section{SIMPULAN}

Hasil simulasi untuk pemilihan calon pejabat struktural Kepala Subbagian Sistem Informasi , urutannya adalah : Topan S.T., M.M. nilai 0.409, Andi, S.E.,
M.M. skor 0.389 dan Ikhsan Riyanda, S.E., M.M. skor 0.202 . Tidak bisa dipungkiri bahwa sistem pendukung keputusan ini belum sepenuhnya bersifat obyektif karena input manusia masih berperan 
besar, namun diharapkan dengan adanya sistem ini proses penentuan Pejabat Kopertis Wilayah III dapat lebih obyektif jika dibandingkan dengan cara manual sebelumnya.

Untuk masa mendatang diharapkan agar program aplikasi dapat lebih ditingkatkan kemampuannya khusus-nya melalui penambahan subkriteria yang digunakan sebagai dasar pertimbangan.

\section{DAFTAR PUSTAKA}

Daihani, D.U. 2001. Komputerisasi Pengambilan Keputusan. Jakarta: Elex Media Komputindo.

Ellitan, L. 2002. "Praktik-Praktik Pengelolaan Sumber Daya Manusia dan Keunggulan Kompetitif Berkelanjutan". Jurnal Manajemen \& Kewirausahaan, 4(2), 65-76.

Koni, S. 2014. "Membangun Sumber Daya Manusia (SDM) Bangsa melalui Pendidikan Karakter". Tadbir: Jurnal Manajemen Pendidikan Islam, 2(2), 179-186.

Kosasi, S. 2002. "Sistem Penunjang Keputusan (Decision Support System)". Proyek Peningkatan Penelitian Pendidikan Tinggi Direktorat Jenderal Pendidikan Tinggi Departemen Pendidikan Nasional, Pontianak.
Kusrini. 2007. Konsep dan Aplikasi Sistem Pendukung Keputusan. Yogyakarta: Andi.

Muhyadi. 2013. "Kualifikasi dan Kompetensi Tenaga Administrasi Sekolah di Daerah Istimewa Yogyakarta". Jurnal Kependidikan, 43(1), 39-50.

Nasibu, I.Z. 2009. "Penerapan Metode AHP dalam Sistem Pendukung Keputusan Penempatan Karyawan Menggunakan Aplikasi Expert Choice". Jurnal Pelangi Ilmu, 2(5), 180-194.

Saaty, T.L. 1990. The Analytic Hierarchy Process. New York: McGraw-Hill.

Salabi, A. "Analisis Proses Internal Keefektifan Organisasi Madrasah Aliyah Negeri di Provinsi Kalimantan Selatan". Jurnal Kependidikan, 44(2), 117-126.

Tominanto. 2012. “Sistem Pendukung Keputusan dengan Metode Analytical Hierarchy Process (AHP) untuk Penentuan Prestasi Kinerja Dokter pada RSUD". INFOKES, 2(1). Wagiran, Munadi, S., \&Widodo, S.F.A. 2014. "Pengembangan Model Penguatan Soft Skills dalam Mewujudkan Calon Guru Kejuruan Profesional Berkarakter". Jurnal Kependidikan, 44(1), 92-102. 